ISSN 0103-5150

Fisioter. Mov., Curitiba, v. 27, n. 3, p. 309-317, jul./set. 2014

Licenciado sob uma Licença Creative Commons

DOI: http://dx.doi.org.10.1590/0103-5150.027.003.A001

\title{
The use of Virtual Reality for upper limb rehabilitation of hemiparetic Stroke patients
}

\author{
A utilização da Realidade Virtual para recuperação do membro \\ superior de pacientes hemiparéticos por Acidente Vascular Cerebral
}

\section{Antonio Vinicius Soares ${ }^{[a]}$, Simone Suzuki Woellner ${ }^{[b]}$, Camile dos Santos Andrade ${ }^{[c]}$, Thiago Julian Mesadri ${ }^{[c]}$, Alessandro Diogo Bruckheimer ${ }^{[\mathrm{d}]}$, Marcelo da Silva Hounsell ${ }^{[\mathrm{e}]}$}

[a] MSc, professor, Faculdade Guilherme Guimbala, Núcleo de Pesquisas em Neuroreabilitação, Joinville, SC - Brazil, e-mail: a.vinisoares@yahoo.com.br

[b] Specialist, professor, Faculdade Guilherme Guimbala, Curso de Fisioterapia, Joinville, SC - Brazil, e-mail: simones.woellner@gmail.com

[c] Graduate, Faculdade Guilherme Guimbala, Curso de Fisioterapia, Joinville, Joinville, SC - Brazil, e-mails: txulian@gmail.com; camile.s.andrade@gmail.com

[d] Graduate, Universidade do Estado de Santa Catarina, Joinville, SC - Brazil, e-mail: alebruck@gmail.com

[e] PhD, Universidade do Estado de Santa Catarina, Departamento de Ciências da Computação, Joinville, SC - Brazil, e-mail: marcelo.hounsell@udesc.br

\section{Abstract}

Introduction: The Stroke is a neurologic disturbs that leads to a serious impact to the functionality and the quality of life of the survivors. It is necessary to develop new tools with rehabilitation objectives, where the Virtual Reality (VR) is introduced as a useful therapeutic resource to the motor recovery, in an attractive and efficient way, restoring functions through adapted games. Objective: Analyzing the therapeutic effects of the Virtual Reality (Serious Game) in the recovery of the upper limb in hemiparetic Stroke patients. Methods: Quasi-experimental research type time series, there are three pre and three post-tests already accomplished around $20 \mathrm{VR}$ sessions. In the assessments the following measurement instruments were used: Fugl-Meyer Scale - session of the upper limb (FMS - UL); Range of Motion (ROM) for flexion and abduction shoulder; Box and Block Test (BBT); Nine Holes and Peg Test (9HPT); the Nottingham Health Profile (NHP); and the Modified Ashworth Scale (MAS). Results: Significant gains were observed in the FMS-UL tests, with 
increase of $25.6 \%$; increase ROM of shoulder with $34.0 \%$ for abduction and $19 \%$ for flexion; BBT $25.0 \%$; also reported improvement in quality of life by NHP; it did not occurred significant alterations for 9HPT nor in MAS. Conclusion: Although the results found in this research are preliminary, they are indicative that the VR can contribute for the recovery of the upper limb in hemiparetic Stroke patients.

Keywords: Stroke. Hemiparesis. Virtual Reality.

\section{Resumo}

Introdução: O Acidente Vascular Cerebral (AVC) é um distúrbio neurológico que acarreta grave impacto na funcionalidade e na qualidade de vida dos sobreviventes. Faz-se necessário o desenvolvimento de novas ferramentas com fins reabilitacionais, neste contexto, a Realidade Virtual (RV) apresenta-se como um recurso terapêutico útil para recuperação motora, de forma atrativa e eficiente, restaurando funções por meio de jogos adaptados. Objetivo: Analisar os efeitos terapêuticos da Realidade Virtual (Jogo Sério) na recuperação do membro superior de pacientes hemiparéticos por AVC. Métodos: Pesquisa quase experimental tipo séries de tempo, havendo realização de três pré e três pós-testes após 20 sessões de RV. Nas avaliações foram utilizados os seguintes instrumentos de medida: Escala de Fugl-Meyer - sessão do membro superior (EFM-MS); amplitude de movimento (ADM) para flexão e abdução do ombro; Teste da Caixa e Blocos (CB); Teste de Nove Buracos e Pinos (9BP); o Perfil de Saúde de Nottingham (PSN); e Escala de Ashwhorth Modificada (EAM). Resultados: Ganhos significativos foram observados nos testes da EFMMS, com incremento 25,6\%; ADM do ombro com 34,0\% para abdução e 19,8\% para flexão; CB 25,0\%; os pacientes também relataram melhora na qualidade de vida pelo PSN; não ocorreram alterações significativas para 9BP e na EAM. Conclusão: Embora os resultados encontrados nesta pesquisa sejam preliminares, eles são sugestivos de que a $R V$ pode contribuir para a recuperação do membro superior de hemiparéticos por AVC.

Palavras-chave: Acidente Vascular Cerebral. Hemiparesia. Realidade Virtual.

\section{Introduction}

The Stroke is a great public health problem in Brazil and all over the world. It represents the largest cause of morbid-mortality in all Latin America (1). In a study made in Joinville (SC) between 2005 and 2007, it was demonstrated a gross incidence of 69.5/100,000 (91.6 when adjusted to the population of Brazil and 135.7 when adjusted to the world population - WHO). This incidence has been reduced around $27 \%$ in the last decade in the city (2). Even though, the Stroke continues representing the greatest cause of mental and physical incapacity in adults $(3,4)$.

Several factors interfere with the functionality of the hemiparetic patient, as the abnormal sequence of the muscular activation, the presence of spasticity, loss of muscle strength, dexterity and coordination. Great functional impact is experimented by the patient, because the upper limb, due to the complexity of the functions $(5,6)$.

The advances in the recovery/rehabilitation process in patients stricken with Stroke are based on concepts of neuroplasticity and reorganization of the cerebral activity. These advances have also demonstrated the diversity and complexity of reorganization patterns, suggesting that the process of reorganization is dynamic and depends on the lesion nature, its course time, so as the adaptation of the collateral physiologic circulation in order to minimize the progress of the lesion (7).

The technological range variety of the Virtual Reality (VR), because the way of Serious Games has been used with the objective of providing therapeutic and recreational challenges (8). This implementation is mainly based on the hypothesis that, when an individual is exposed to his own image (like a mirror) performing a motor task, it occurs at cortical level, effects of reorganization by neuroplastic mechanisms which can reorganize the injury motor cortex, by the mean of mirror`s neurons activation $(9,10,11)$.

The system of Virtual Reality permits the interaction of the users with a world created by computer with performance by his own image. In the 
rehabilitation the VR permits that people with any deficiency caused by neurologic injuries find a way to reach the best motor strategy in a virtual environment to accomplish a specific task (12).

In the exercise in a VR environment, the individuals can control their own movements and try to reproduce required standard movements to accomplish the task that are shown in real time in the virtual scenery. The environments created with the VR can be interactive, or even, only having the increase of effects on the environment in which the individual is, and they can be manipulated to adequate the individual treatment, improving in this way the motor control. The VR can also minimize the adaptation and avoid boredom, and therefore support the attention by valuing the environment diversity (13).

The objective of this research was to analyze the therapeutic effects of the Virtual Reality (Serious Game) in the recovery of the upper limb of hemiparetic Stroke patients.

\section{Methods}

The study was approved by Human Research Ethics Committee of the Lutheran Educational Association (number 016/2011). After clarification and orientations all the participants gave their written informed consent.

The design of the research was almost experimental type time series where three pre and three post-tests were applied in alternate days. All the assessments and applications of the game were carried out in the Center for Research Neurorehabilitation from the Guilherme Guimbala College. All the tests were always applied by the same examiner.

Six patients with hemiparesis were submitted to the training program with the VR. They were receiving treatment at the Neurologic Physiotherapy Ambulatory of the institution above mentioned that is the accredited entity. During the project, the participants received physiotherapy based on classic kinesiotherapy. The upper limbs were only mobilized passively before the sessions of VR.

All the patients involved in the research have hemiparesis post-Stroke, having as exclusion criteria: other causes of hemiparesis, severe cognitive, visual and/or auditory impairments. The Table 1 shows the characteristics of the participants of the study.
Table $\mathbf{1}$ - Characteristics of the participants

\begin{tabular}{lcc}
\hline & Average & Range/\% \\
\hline Age, years ( $\pm \mathrm{SD})$ & $53.7( \pm 9.5)$ & $35-60$ \\
Gender (men/women) & $5 / 1$ & $83.3 / 16.7$ \\
Lesion time (months) & $15.8( \pm 4.3)$ & $2-41$ \\
Affected hand (right/left) & $3 / 3$ & $50 / 50$ \\
$\begin{array}{l}\text { Type of Stroke } \\
\text { (Ischemic/hemorrhagic) }\end{array}$ & $6 / 0$ & $100 / 0$ \\
Affected Dominant Hand & 3 & 50 \\
\hline
\end{tabular}

Source: Research data.

\section{Measurement instruments}

The measurement instruments used were the Fugl-Meyer Scale - session of the upper limb, the shoulder goniometry (flexion and abduction), the Box and Blocks Test, the Nine Holes and Pegs Test, the Modified Ashwhorth Scale and the Nottingham Health Profile.

The Fugl-Meyer Scale (FMS) is a system of accumulative numerical score that was applied in a modified way, evaluating exclusively the paretic upper limb. The aspects of the analysis consisted in the range of motion and the motor function of the upper limb, scoring 60 points. An ordinal scale of three points is applied in each item: 0- can't be fulfilled, 1- partially fulfilled, and 2- totally fulfilled (14). This complete scale has a total of 100 points for the normal motor function. The score is determined according to the level of motor injury, in which less than 50 points indicates a severe motor injury; 50-84 remarkable; 85-95 moderate; and 96-99 light (14).

In the evaluation of the manual dexterity the Nine Hole Peg Test - NHPT with nine pegs ( $9 \mathrm{~mm}$ diameter and $32 \mathrm{~mm}$ length), a wood board with 100x100x20 dimension containing nine holes of $10 \mathrm{~mm}$ diameter and $15 \mathrm{~mm}$ depth $(11,12)$. The patient was oriented to take off all the pegs from the board and put them back. The patient was allowed to get familiar with the instrument during 15 seconds, and then he was supposed to fulfill the task in not more than 120 seconds; the Box and Blocks Test - BBT that is compound by a wood box (53.7 $\mathrm{cm}$ length) with a dividing wall higher than the borders, separated into two same dimension compartments and 150 cubes of $2.5 \mathrm{~cm}$ 
(15). The patient transported the blocks from one side to the other of the box, being oriented to do it firstly for 15 seconds to get familiar with the test. In sequence, one minute was timed and the number of transported blocks was counted. For both tests a verbal command was used, directing the patient to accomplish the task as fast as he could (16).

The Modified Ashworth Scale: the physiotherapist performs a quick movement against the muscle, verifying if this one presents any resistance. The score varies from 0 to 5 , being 0 normal, where there is no muscular tonus increase and 5 - severe spasticity, the affected segment is rigid in flexion or extension (17).

The Nottingham Health Profile (NHP) is a generic instrument for quality of life assessment, originally developed to evaluate patients with chronic diseases (18). It is a questionnaire, constituted of 38 items, based on the classification of incapacity described by the World Health Organization, with responses in the formatyes/ no. The items are organized in six categories that include level of energy, pain, emotional reactions, sleep, social interactions and physical abilities. Each positive response corresponds to a score from one (1) and each negative response corresponds to a score zero (0), bringing up to the maximum score of 38 (18).

\section{Procedures}

After the initial evaluations the patients were submitted in average to 20 sessions with the Dance Rain Game (D2R2) (19). This game was developed by LARVA (Laboratory of Research on Visual Applications) on Santa Catarina State University.

In each session the patient was submitted to the passive mobilization of the upper limb for about 10 minutes. Subsequently he was oriented to remain sat in front of the webcam, in a distance of two meters in between. The patient then interacted with the projection of his own image in natural size. The position of the patient during the game is presented in Figure 1.

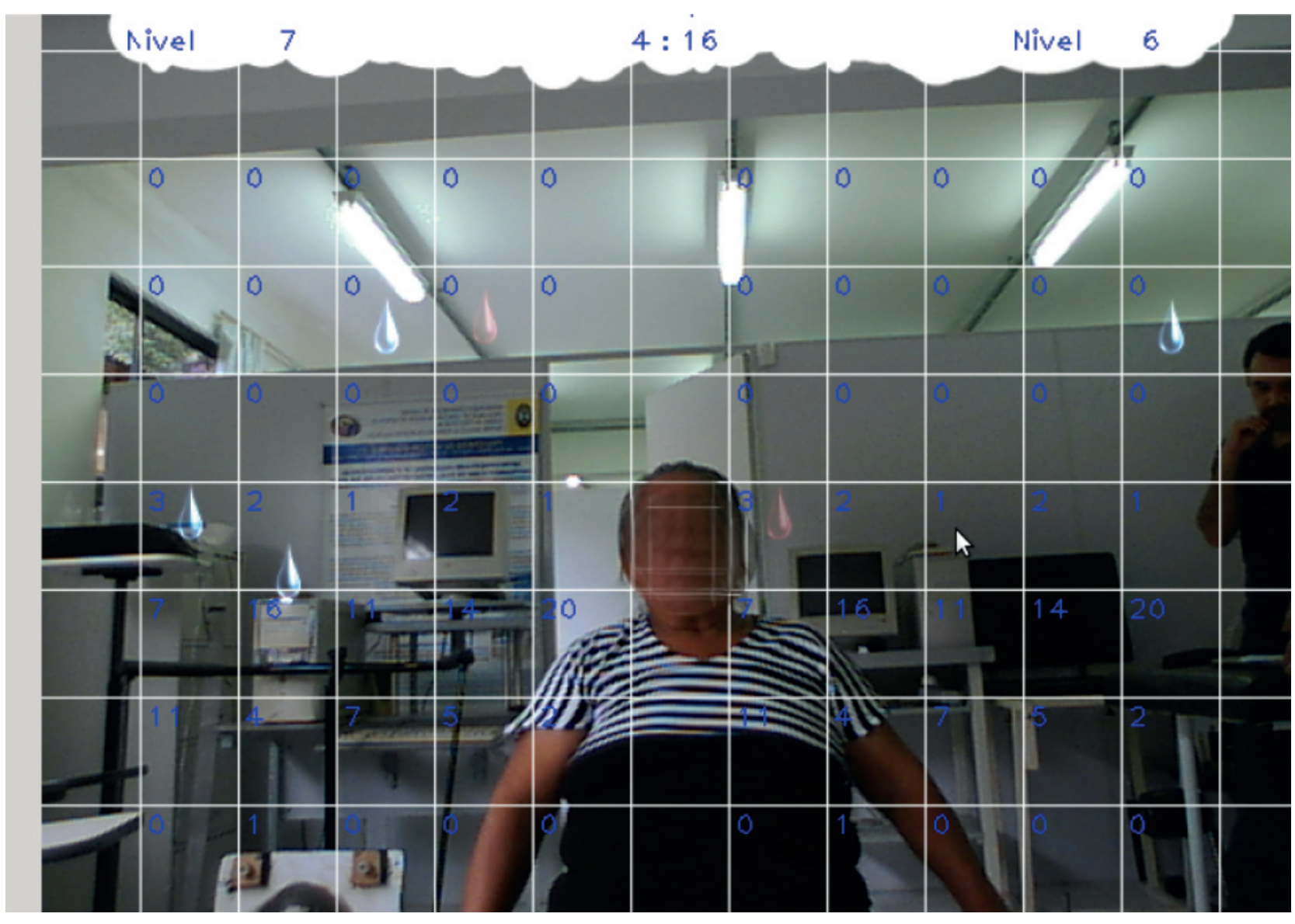

Figure 1 - Patient on Dance Rain - Serious Game Source: Research data. 
The systematic of the game consists on the patient's interaction with his own image, being necessary mutual action of graphic elements inserted in a dynamic way. In this case the task was to prevent that the raindrops launched randomly cross the scenery in the longitudinal direction. Each match has five minutes, in which the patient is oriented to touch the largest number of drops he can. The five minutes-matches is divided in three steps: the first step that is adjusted by the therapist before the start of the match, the raindrops fall only on the middle of the captured image in which the affected hemibody is. After one minute and forty seconds, the game directs automatically the distribution of raindrops to the other half of the captured image, and after one minute and forty seconds more, the raindrops fall onto two halves of the captured image, the patient is then exposed to the activity in a bilateral way. The patient was oriented to play in his conditioning limits, without being exhausted. The patients played in general between 15 to 30 minutes.

For the use of the game D2R2 it was necessary to have a PlayStation Eye ${ }^{\circledR}$ webcam, a computer with a $2.2 \mathrm{GHz}$ AMD processor, RAM 3GB DDR3 memory and graphic hardware and an Epson S4 1800 Lumens Projector.

\section{Data analysis}

The collected data were tabulated on Microsoft Office Exce $\mathrm{I}^{\circledR} 2007$, and exported to the software Graph
Pad Prism $4{ }^{\circledR}$ where the minimum and maximum values, the average and the standard deviation were determined. The Wilcoxon Test was applied for the data not parametric with significance level 95\% ( $\mathrm{p} \leq 0.05)$ in order to verify whether the differences between the values of pre and post-tests were meaningful.

\section{Results}

The results demonstrated below are based on a research where measurement instruments were used. On Table 2, the results of the tests that were applied on the patients that took part in the research are expressed.

After 20 sessions between 15 and 30 minutes of duration in the Dance Rain game, it was observed an increase of $25.6 \%$ on the performance of Fugl-Meyer Scale, an increment of ROM abduction and flexion shoulder (34\% and $19.8 \%$, respectively). These gains were significant according to the data presented on Table 2. In the Box and Blocks Test, there was an improvement of $25 \%$ on the performance, being also statistically significant.

Although there has been occurred some improvements on the Nine Hole and Peg Test and on the Modified Ashworth Scale, those alterations were not significant.

In the assessment of quality of life through the Nottingham Health Profile, there was an average of $10.5 \%$ improvement in quality of life. The Figure 2 present details these results.

Table 2 - Descriptive statistics and performance index

\begin{tabular}{|c|c|c|c|c|c|c|c|c|c|c|c|c|}
\hline & $\begin{array}{l}\text { FMS } \\
\text { pre }\end{array}$ & $\begin{array}{l}\text { FMS } \\
\text { post }\end{array}$ & $\begin{array}{l}A B \\
\text { pre }\end{array}$ & $\begin{array}{l}A B \\
\text { post }\end{array}$ & $\begin{array}{l}\mathrm{FL} \\
\text { pre }\end{array}$ & $\begin{array}{l}\text { FL } \\
\text { post }\end{array}$ & $\begin{array}{l}\text { BBT } \\
\text { pre }\end{array}$ & $\begin{array}{l}\text { BTB } \\
\text { post }\end{array}$ & $\begin{array}{c}\text { 9HPT } \\
\text { pre }\end{array}$ & $\begin{array}{l}\text { 9HPT } \\
\text { post }\end{array}$ & $\begin{array}{c}\text { MAS } \\
\text { pre }\end{array}$ & $\begin{array}{l}\text { MAS } \\
\text { post }\end{array}$ \\
\hline Minimum & 19 & 46 & 67 & 98 & 87 & 113 & 8.7 & 12 & 26 & 30 & 0.0 & 0.0 \\
\hline Maximum & 56 & 57 & 180 & 180 & 180 & 180 & 43 & 51 & 120 & 120 & 1.8 & 1.7 \\
\hline Average & 43 & 54 & 94 & 126 & 116 & 139 & 28 & 35 & 82 & 80 & 0.68 & 0.59 \\
\hline SD & 15 & 5 & 43 & 31 & 35 & 23 & 12 & 15 & 42 & 45 & 0.81 & 0.80 \\
\hline PI & \multicolumn{2}{|c|}{$\uparrow 25.6 \%$ * } & \multicolumn{2}{|c|}{$\uparrow 34.0 \%$ * } & \multicolumn{2}{|c|}{$\uparrow 19.8 \%$ * } & \multicolumn{2}{|c|}{$\uparrow 25.0 \%$ * } & \multicolumn{2}{|c|}{$\downarrow 2.4 \%$} & \multicolumn{2}{|c|}{$\downarrow 13.2 \%$} \\
\hline
\end{tabular}

Note: FMS = Fugl-Meyer Scale $-\mathrm{UL}$ session (0-60); $\mathrm{AB}=$ Shoulder abduction goniometry (degrees); $\mathrm{FL}=$ Shoulder flexion goniometry (degrees); BBT = Box and Blocs Test (blocs/min); 9HPT = Nine Hole and Peg Test (time, sec); MAS = Modified Ashworth Scale (0-5); $\mathrm{SD}=$ Standard Deviation; $\mathrm{PI}=$ Performance Index. ${ }^{*} \mathrm{p} \leq 0.05$

Source: Research data. 


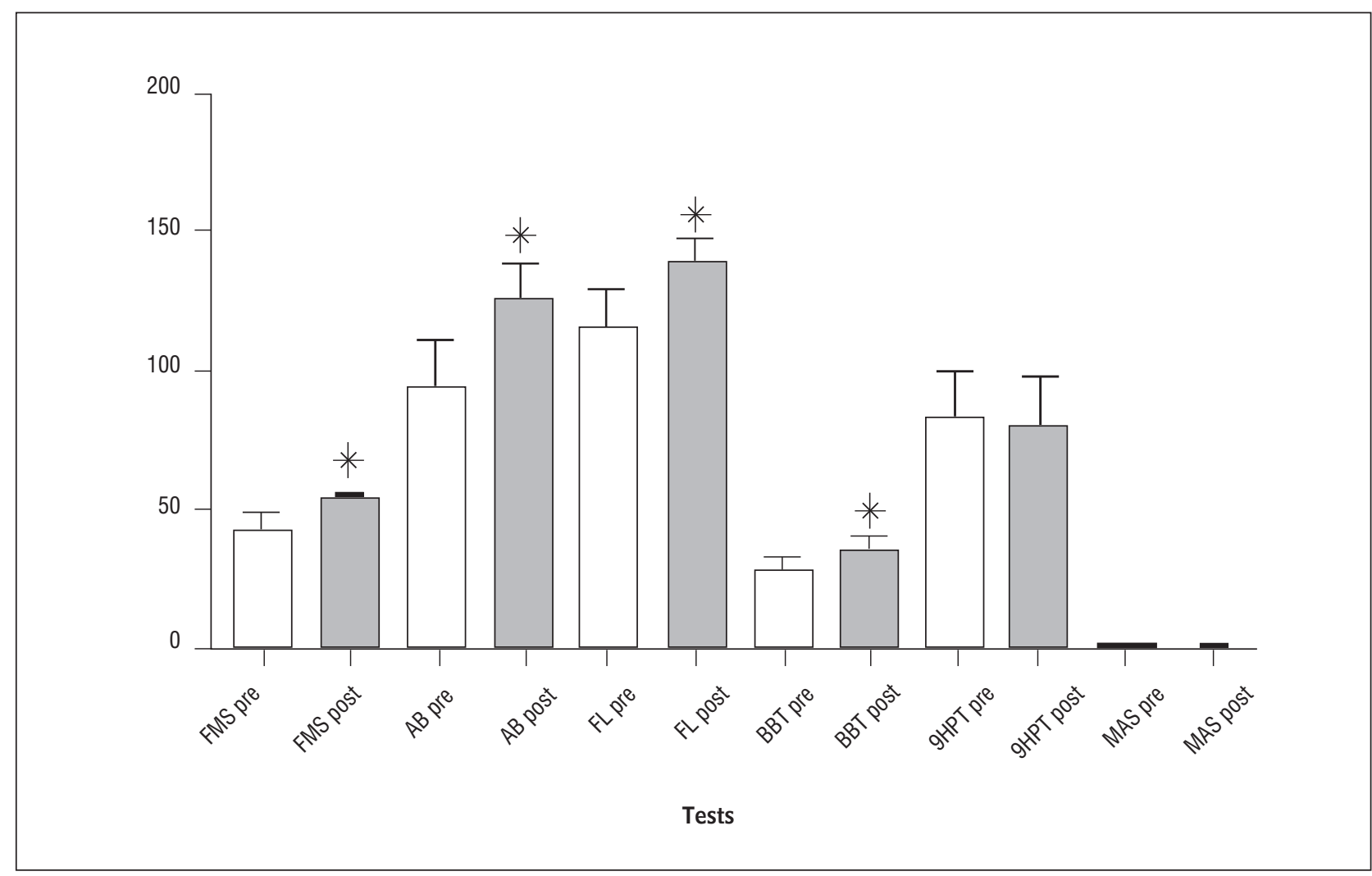

Figure 2 - Main tests used of study

Note: FMS = Fugl-Meyer Scale (UL session); $A B=$ Shoulder abduction goniometry; FL = Shoulder flexion goniometry; BBT = Box and Blocs Test; 9HPT $=$ Nine Hole and Peg Test; MAS = Modified Ashworth Scale. $* p \leq 0.05$.

Source: Research data.

\section{Discussion}

The system of VR used in this research is not a commercial system therefore it renders difficult the straight comparison of the results with other researches. This VR system in a form of Serious Game was developed and tested only with this group of patients. Even though, it is possible to discuss in general terms, assuming that the basic principle of the playability is represented by the interaction of the patient with the technology in the form of a serious game. This principle is as shared by commercial systems as by prototype software $(7,8),(20,21,22,23,24,25)$.

According to some studies the VR is a potential induction resource of neuroplastic mechanisms to explain the improvement in patients survivors of Stroke (7), $(21,22,23,24,25,26,27,28)$. The researches indicate the possible mechanisms as being: the regression of the perilesional inhibition (reversion of the ischemic penumbra), intracortical disinhibition with a greater activation of the contralateral motor cortex to the lesion and the activation of neuronal mirror populations (7), (23).

Our results with implementation of VR like a therapeutic resource has brought several benefits to the patients that were involved in this rehabilitation program. The improvement in the motor recovery of upper limb was observed in patients here are congruent with other studies, such as in the measurements of Fugl-Meyer Scale (13), (23), (27, 28), in the Box and Blocks Test (22), (27), and in the active ROM shoulder (29).

Piron et al. (28) used the VR to recuperate the upper limb in hemiparetic Stroke patients. Two groups were formed in a sample of 36 patients, where the controlled group received conventional rehabilitation based in classical kinesiotherapy, and the experimental group, a combined approach of VR and telemedicine. Although both groups have improved in the post-tests (Fugl-Meyer Scale, Abilhand and Ashworth Scale), there was a greater increased in the VR group. 
The patients of the study improves the score of Fugl-Meyer Scale, in active ROM shoulder and even in the Box and Blocks Test, it seems to occurs from the growth of the muscular strength and consequently from the active mobility. Even for the Box and Blocks Test, that is used to evaluate the dexterity of the upper limb where it required standard of coordinate movements of the upper limb as a whole, and not only of the distal component, because the hand, something that is invariably required in tests as the Nine Holes and Pegs one. This one, although has improved the final scores, was not significant.

In a review about the use of VR in motor rehabilitation patients post-Stroke, Lucca (21) reviewed nine studies observing several varied row of researches, inclusion/exclusion criteria, number of patients and different VR systems. The reviewed studies also presented positive results in different measurement instruments, especially in the Fugl-Meyer Scale and the Box and Blocks Test. The author also emphasizes the necessity to enlarge the research with stronger methodological alignments.

Relating to the aspects referring to the spasticity, the findings that were found with the Ashworth Modified Scale presented a light degrees spasticity of the upper limb that did not alter significantly the post-tests. Elovic et al. (30) affirms that the growth of the motor function in Stroke patients does not correlate to this scale. The authors explain that although the scale evaluates the passive movement, it does not reflect any functional aspect. The spasticity is further understanding that it is not the more disabling phenomenon in these patients, and that in other aspects, especially the weakness, that seems to represent the greatest impact to the functionality and independence of these patients (4), (31).

Finally, it seems that the program of treatment involving the association of VR with the conventional physiotherapy also improved the patients' perception about their quality of life. This was verified through the application of Nottingham Health Profile. So, there was observed as much objective as subjective improvements in the group of patients.

\section{Final considerations}

Currently, it seems coherent to consider the VR as a therapeutic supporting resource in the process of neurologic rehabilitation. The motivational characteristics, motion repeatability, the induction of the directed movement to a goal, permit the patient a diversity of situations and stimulus, challenging him continuously to accomplish the tasks in a therapeutic context.

Because, the game stimulates the patient in a spontaneous and natural way to move using different motor strategies to each requested challenge in the game, motivating the patient to agree with the treatment. Thus, the greater variability of movements in a therapeutic context and the increased attention and motivational demands are constant requirements. And that seems to provide a new and promising strategy of rehabilitation to those patients.

Even though the given results with the application of this new VR system has been quite positive in the group of involved patients, some limitations can be pointed, as the small number of patients, the lack of a control group, and the comparison with other conventional therapeutic modalities.

Several suggestions were made to implement the game, including the projection in 3D, including tasks based on daily activities, and a system of scoring aiming the correlation with the clinic tests usually used.

It is important that researchers and physiotherapists are willing to test new therapeutic strategies to neurological patients, because the chronic that has limited prognosis and a lot is requirements of adhesion treatment programs. The use of technology is an imminent reality that the professionals cannot neglect for much more time. Indeed, it seems that the VR is a promising tool in the therapeutic means of the modern physiotherapist.

\section{References}

1. Lotufo PA. Stroke in Brazil: a neglected disease. Sao Paulo Med J. 2005;123(1):3-4.

2. Cabral NL, Longo A, Moro C, Ferst P, Oliveira FA, Vieira $\mathrm{CV}$, et al. Education level explains differences in stroke incidence among city districts in Joinville, Brazil: a three-year population-based study. Neuroepidemiology. 2011;36(4):258-64.

3. Kwakkel G, van-Peppen R, Wagenaar RC, WoodDauphinee S, Richards C, Ashburn A, et al. Effects of augmented exercise therapy time after stroke: a metaanalysis. Stroke. 2004;35(11):2529-39. 
4. Teixeira-Salmela LF, Oliveira ESG, Santana EGS, Resende GP. Fortalecimento muscular e condicionamento físico em hemiplégicos. Acta Fisiatr. 2000;7(3):108-18.

5. Ovando AC, Michaelsen SM, Carvalho T, Herber V. Avaliação da aptidão cardiopulmonar em indivíduos com hemiparesia após acidente vascular encefálico. Arq Bras Cardiol. 2011;96(2):140-7.

6. Popovic MB, Popovic DB, Sinkjaer T, Stefanovic A, Schwirtlich L. Clinical evaluation of Functional Electrical Therapy in acute hemiplegic subjects. J Rehabil Res Dev. 2003;40(5):443-54.

7. Kalra L, Ratan R. Recent advances in stroke rehabilitation 2006. Stroke. 2007;38(2):235-7.

8. Laver K, George S, Thomas S, Deutsch JE, Crotty M. Virtual Reality for Stroke Rehabilitation. Stroke. 2012; 43:e20-e21.

9. Wiederhold BK, Wiederhold MD. Virtual reality with fMRI: a breakthrough cognitive treatment tool. Virtual Reality. 2008;12(4):259-67.

10. Edmans JA, Gladman JRF, Cobb S, Sunderland A, Pridmore T, Hilton D, et al. Validity of a virtual environment for stroke rehabilitation. Stroke. 2006; 37(11):2770-5.

11. Holden MK, Dyar TA, Schwamm L, Bizzi E. Virtualenvironment-based telerehabilitation in patients with stroke. Presence. 2005;14(2):214-33.

12. Foulds RA, Saxe DM, Joyce-III AW, Adamovich S. Sensory-motor enhancement in a virtual therapeutic environment. Virtual Reality. 2008;12(2):87-97.

13. Broeren J, Rydmark M, Björkdahl A, Sunnerhagen KS. Assessment and training in a 3-dimensional virtual environment with haptics: a report on 5 cases of motor rehabilitation in the chronic stage after stroke. Neurorehabil Neural Repair. 2007;21(2):180-9.

14. Faria I. Função do membro superior em hemiparéticos crônicos: análise através da classificação internacional de funcionalidade, incapacidade e saúde (dissertação). Belo Horizonte: Universidade Federal de Minas Gerais; 2008.

15. Mendes MF, Tilbery CP, Balsimelli S, Moreira MA, Cruz AMB. Teste de destreza manual da caixa e blocos em indivíduos normais e em pacientes com esclerose múltipla. Arq Neuropsiquiatr. 2001;59(4):889-94.
16. Huter-Becker A, Dolken M. Fisioterapia em neurologia. São Paulo: Santos; 2008.

17. Blackburn M, van-Vliet P, Mockett SP. Reliability of measurements obtained with the modified Ashworth scale in the lower extremities of people with stroke. Phys Ther. 2002;82(1):25-34.

18. Teixeira-Salmela LF, Magalhães LC, Souza AC, Lima MC, Lima RC, Goulart F. Adaptação do Perfil de Saúde de Nottingham: um instrumento simples de avaliação da qualidade de vida. Cad Saude Publica. 2004; 20(4):905-14.

19. Bruckheimer AD, Hounsell MS, Soares AV. The design of a virtual rehabilitation game the design of a virtual rehabilitation game. In: Proceedings of IADIS International Conference Applied Computing; 2011 6-8 Nov; Rio de Janeiro.

20. Saposnik G, Teasell R, Mamdani M, Hall J, McIlroy W, Cheung D, et al. Effectiveness of virtual reality using Wii gaming technology in stroke rehabilitation: a pilot randomized clinical trial and proof of principle. Stroke. 2010;41(7):1477-84.

21. Lucca LF. Virtual reality and motor rehabilitation of the upper limb after stroke: a generation of progress? J Rehabil Med. 2009;41(12):1003-100.

22. Burke JW, McNeill MDJ, Charles DK, Morrow PJ, Crosbie JH, McDonough SM. Optimising engagement for stroke rehabilitation using serious games. Vis Comput. 2009;25(12):1085-99.

23. Jang SH, You SH, Hallett M, Cho YW, Park CM, Cho SH, et al. Cortical reorganization and associated functional motor recovery after virtual reality in patients with chronic stroke: an experimenter-blind preliminary study. Arch Phys Med Rehabil. 2005;86(11):2218-23.

24. You SH, Jang SH, Kim YH, Hallett M, Ahn SH, Kwon YH, et al. Virtual reality-induced cortical reorganization and associated locomotor recovery in chronic stroke: an experimenter-blind randomized study. Stroke. 2005,36(6):1166-71.

25. Teasell RW, Kalra L. What's new in stroke rehabilitation. Stroke. 2004;35(2):383-5.

26. Merians AS, Jack D, Boian R, Tremaine M, Burdea GC, Adamovich SV, et al. Virtual reality-augmented rehabilitation for patients following stroke. Phys Ther. 2002;82(9):898-915. 
27. Saposnik G, Levin M. Virtual reality in stroke rehabilitation: a meta-analysis and implications for clinicians. Stroke. 2011;42(5):1380-6.

28. Piron L, Turolla A, Agostini M, Zucconi C, Cortese F, Zampolini M, et al. Exercises for paretic upper limb after stroke: a combined virtual-reality and telemedicine approach. J Rehabil Med. 2009;41(12):1016-102.

29. Subramanian SK, Lourenço CB, Chilingaryan G, Sveistrup H, Levin MF. Arm motor recovery using a virtual reality intervention in chronic stroke: randomized control trial. Neurorehabil Neural Repair. 2013; 27(1):13-23.

30. Elovic EP, Simone LK, Lafonte R. Outcome assessment for spasticity management in the patient with traumatic brain injury: the state of the art. J Head Trauma Rehabil. 2004;19(2):155-77.
31. O'Dwyer NJ, Ada L, Neilson PD. Spasticity and muscle contracture following stroke. Brain. 1996; 119(5):1737-49.

Received: $12 / 21 / 2013$

Recebido: 21/12/2013

Approved: 06/09/2014

Aprovado: 09/06/2014 